\title{
The Effect Of Organizational Culture On Performance Of Govern- ment Internal Supervisory Apparatus (Apip) In The National Indone- sian Navy
}

\author{
Soetjahjo Niti Tisno Harijono \\ Universitas Negeri Jakarta, Indonesia \\ E-mail: soetjahjoniti_im12s3@mahasiswa.unj.ac.id
}

\section{Billy Tunas}

Universitas Negeri Jakarta, Indonesia

E-mail: tunas.billy@gmail.com

\section{Hamidah}

Universitas Negeri Jakarta, Indonesia

E-mail: hamidah@unj.ac.id

\begin{abstract}
Every Government Internal Supervisory Apparatus aims to improve performance through organizational Culture. The purpose of this study is analyzing the influence of organizational culture on the performance of government internal supervisors in the National Indonesian Navy. This research use quantitative study by using the Path Analysis method with a sample of 96 Government Internal Supervisors. The results of the study show that there is a direct influence of organizational culture on performance. Thus, the national Indonesian navy should put more attention regarding the Organizational Culture including discipline, efficiency, ethics, scope of work, work orientation and work implementation instructions.
\end{abstract}

\footnotetext{
Keywords:

Organizational Culture, Performance National Indonesian Navy
}

Received: 19 July 2019 ;

Accepted: 1 August 2019;

Publish: October 2019.

\section{How to Cite:}

Harijono, S. N. T., Tunas, B., Hamidah, H.. (2019). The Effect Of Organizational Culture On Performance Of Government Internal Supervisory Apparatus (Apip) In The National Indonesian Navy. Journal of Business and Behavioural Entrepreneurship, 3(1), 27-32.

https://doi.org/10.21009/JOBBE.003.1.03 


\section{INTRODUCTION}

Today's demands by filling in various sources of disciplines that have been owned, reflecting on the experience that has been carried out and the dense schedule of Supervision and the extent of performance in carrying out tasks. Government Internal Supervisory Apparatus (APIP) is a Government Agency that has the main task and function of carrying out supervision. The study sample used 96 APIP personnel to first use 30 APIP Personnel to test the data questionnaire, the results obtained as follows: 1. Assessment that did not change as many as 15 APIP personnel or 50\%; 2. The judgments that experienced changes were 15 APIP personnel or $50 \%$. Facing these conditions, APIP is required to be able to overcome the mismatch of daily tasks by prioritizing the main tasks and functions that can improve performance with organizational culture, job satisfaction, motivating, and trust. According Sarmaz and IIic (2016), Organizational culture should be cultivated, set in the fuction of company's success, but its negative impact should be avoided.

Identification of the problem, Nothing the potential factors for the existing performance in the Navy's APIP. These factors include internal and external factors, by prioritizing basic tasks and functions. Based on the identification of the problem, this research can be formulated, whether the organizational culture has a direct effect on performance.

\section{THEORETICAL DESCRIPTION}

Performance is a value of a set of employee behaviours given to the agency where they work. According to Colquit, LePine, and Wesson, (2009), Performance is the value of a set of employee behaviours that have been contributed positively and negatively to meet organizational goals. Organizational Culture, Organizational culture grows because it was created and developed by individuals who work in an organization that is accepted as values that must be maintained and passed on to each new member. Luthan (2011), Some of the important characteristics of organizational culture are observed behavioural regularities, norms, dominant values, philosophy, rules, and organizational climate. Although everyone in an organization will share the organization's culture, not all may do so to the same degree.

Relevant research, To be able to support this research by reflecting on previous relevant research. According to Amin Nikpour (2017), it shows that organizational culture has a positive and significant impact on organizational performance.

Theoretical framework, Organizational culture grows because it was created and developed by individuals who work in an organization that is accepted as values that must be maintained and passed on to each new member. According to Luthans (2011), Ethics is involved with moral issues and choices and deals with right and wrong behaviour. A number of cultural (family, friends, neighbours, education, religion, and the media), organizational (ethical codes, role models, policies and practices, and reward and punishment systems), and external forces (political, legal, economic, and international developments) help determine ethical behaviour. These influences, act interdependently, serve to help identify and shape ethical behaviour in today's organizations. There is increasing evidence of the positive impact that ethical behaviour and corporate social responsibility programs have on "bottom-line" performance.

Performance of individual performance that has been contributed positively to complete the organizational goals, namely: the implementation of routine and addition-

* The Effect Of Organizational Culture On Performance Of Government Internal Supervisory Apparatus (Apip) In The National Indonesian Navy. 
al tasks, efforts to improve the organization, willingness to exceed the assigned tasks, the ability to provide a positive image of the organization, the willingness to provide relevant information, the ability to maintain good behaviour. According to Salihu, Adam Jiddah, Salihu, Muhammad Bello Rayyan \& Musa Idris Umar (2016), Management must focus more on adherence to the organization's mission by ensuring that they are in leadership positions that are well versed in the organization's mission so that they can pass on to their subordinates, Likewise, management must work on ethical practices from organizations such as credibility and integrity that promote a highperformance culture. Based on the description above, it is suspected that there is a direct influence of Organizational Culture on performance. Based on the theoretical study that underlies the variables of this study and the thinking framework described above, the hypothesis can be proposed namely: H1: It is assumed that there is a direct influence of Organizational Culture on performance. This study aims to obtain empirical data, facts, valid and reliable information about the influence of organizational culture, the Internal Control Officer. This study specifically aims to find out about the direct influence of Organizational Culture on Performance. Research takes place at the Inspectorate of the Navy Headquarters.

\section{RESEARCH METHODS}

Using quantitative approaches with survey methods. Aim to find out and find the momentary position of the variable (qua status variable) based on the data at the time (Qua status data) and the relationship between the variables studied. Population and sampling. The sample used in the study was taken randomly and the sample size was taken proportionally. Data collection techniques, As long as the research is conducted with observations and questionnaire methods used quantitatively, the data needed for this study include primary data and secondary data. Primary data is obtained by distributing questionnaires to qualified personnel on material about Organizational Culture and Performance.

\section{Research instruments;}

1. Performance Variables; a. Conceptual Definition, Performance is the performance of a set of workforce behaviours that have been positively contributed; $b$. Operational Definition, Performance is a work set of labor behaviors that have been positively contributed by the Navy's APIP to be assessed by the Leader. With performance indicators, namely: a routine task implementation; $b$ additional assignment; $c$ discuss the improvement of the organization and the willingness to carry out tasks more than specified; $d$ willingness to give a positive image of the organization; e willingness to help; $\mathrm{f}$ willingness to inform relevant matters; and $\mathrm{g}$ the ability to maintain good behavior; c. Grid of Performance Instruments, Item questions with 5 alternative answers: $\mathrm{A}=$ Always; $\mathrm{O}=$ Often; $\mathrm{S}=$ Sometimes, $\mathrm{R}=$ Rarely; $\mathrm{N}=$ Never. The statement is worth $\mathrm{A}=5 ; \mathrm{O}=4 ; \mathrm{S}=3, \mathrm{R}=2 ; \mathrm{N}=1$; $\mathrm{d}$. Validation Testing and Instrument Reliability calculations Performance variables. Test the validity of the instrument, Pearson Product Moment correlation test and Reliability Test Instrument performance research, by looking at the Alpha coefficient (Cronbach Alpha), using SPSS software version 22.

2. Organizational Culture Variable; a. Conceptual definition, organizational culture is a system of values that are believed, understood, agreed upon, and applied to all employees / personnel to know the relationship between rules, norms, and shared values; b. Operational Definition, Organizational Culture is the perception of APIP on 
organizational cultural values closely related to the rules, norms, and values shared by the Navy's APIP. With indicators of organizational culture: a main value of the agency (discipline and efficiency); b agency norms (ethics and scope of work); c Agency Regulations (Job orientation and work implementation instructions); c. Instrument Grid, Item questions with 5 alternative answers: $\mathrm{SA}=$ Strongly agree; $\mathrm{A}=$ Agree; $\mathrm{NO}=\mathrm{No}$ opinion, $\mathrm{D}=$ Disagree; $\mathrm{SD}=$ Strongly disagree. Statements worth $\mathrm{SA}=5 ; \mathrm{A}=4$; $\mathrm{NO}$ $=3, \mathrm{D}=2 ; \mathrm{SD}=1$.; $\mathrm{d}$. Validation Testing and Instrument Reliability calculations Performance variables. Test the validity of the instrument, Pearson Product Moment correlation test and Reliability Test Instrument performance research, by looking at the Alpha coefficient (Cronbach Alpha), using SPSS software version 22.

Analysis techniques, Using data analysis with descriptive statistical analysis and inferential statistics. Statistical hypothesis. Based on the research hypothesis, statistical hypotheses can be formulated, namely, Organizational Culture (X) has a direct effect on performance $(\mathrm{Y})$.

$\mathrm{H} 0: \beta \mathrm{y} 1 \leq 0 ; \mathrm{H} 1: \beta \mathrm{y} 1>0$

\section{ANALYSIS}

The results of research which includes a description of the data in each research variable, testing requirements analysis, testing the research hypothesis, and discussing the results of the study and the limitations of the study. Descriptions of Research Data, Data collected in this study are data from four variables, including Performance (Y) as Endogenous variable, Organizational Culture (X), as Exogenous variables.; 1. Performance (Y), Using 96 respondents of the study, before the research was carried out the test items were first conducted to 30 respondents by giving 30 questions, but 28 valid results were obtained.; 2. Organizational Culture (X), Using 96 respondents, before the research was carried out the test items were first conducted to 30 respondents by giving 30 questions, but there were 27 valid questions. Analysis requirements, Before the data is analyzed further, to test hypotheses based on existing data, several test requirements for analysis need to be conducted. Testing the analysis requirements for path analysis is the relationship between variables in the model must be linear, so that the regression equation meets the analysis requirements.; 1. Normalization Test, regression estimation error test $\mathrm{Y}$ over $\mathrm{X}$ produces the maximum Lcount price of 0.0864 while Ltable at the level of $\alpha=0.05$ obtained at 0.0904 turns out that Lcount $<$ Ltable or $0.0864<0.0904$. Thus, it can be concluded that the estimation error Y on X is normally distributed. ;2. Regression Significance Test and Linearity and Correlation Test, produced as follows: a. Regression Equations Performance of organizational culture $\mathrm{Y}=60.758+0.545 \mathrm{X}$, obtained Fcount $=59.564$. While Ftable at $\alpha=0.05$ and $\mathrm{dk}=1 / 94$ obtained 6.90 , so Fcount $>$ Ftable or $59.564>6.90$ Thus, it can be stated that the regression coefficient is very significant; b. Linear test results, obtained Fcount $=1.160$ After confirming the Ftable at $\alpha=0.05$ with $\mathrm{dk}=32 / 62$ obtained 1.58 it turns out Fcount $<$ Ftable or. $1.160<1.58$ thus, it can be concluded that the regression equation is linear. c. Correlation coefficient ryl $=0.623$, thest obtained tcount $=$ 7.722 while ttable at $\alpha=0.01$ and $\mathrm{dk}=94$ obtained 2.367 Thus tcount $>$ ttable or $7.722>2.367$, so that the correlation coefficient is significant. Path coefficient calculations, Conduct path analysis, by explaining in advance explained about the relationship between variables in diagrammatic (path diagram) whose shape is determined by theoretical propositions derived from a particular frame of mind and the formulation of research hypotheses. Hypothesis testing, Effect of Organizational Culture on Performance, Hypothesis states that Organizational Culture has a direct effect on Perfor- 
mance. Statistical hypothesis: Ho: $\beta y 1 \leq 0 ; \mathrm{H1}: \beta y 1>0$ The Organizational Culture path coefficient has a direct effect on Performance of $\rho y 1=0.430$, then a significance test is performed with the $t$ test. The ttest calculation results obtained tcount $=4.892$ while ttable $=2.367$ at $\alpha=0.01$ for $\mathrm{dk}=94$ so that tcount $>$ ttable or $4.892>2.367$, then reject $\mathrm{H} 0$ or accept $\mathrm{H} 1$, path coefficient $\rho 1$ significant. Thus Organizational Culture has a positive effect on Performance. According Amin Nikpour, International Journal of Organizational Leadership 6 (2017). The impact of organizational culture on organizational performance: the mediating role of employee's organizational commitment. Indicated that organizational culture has a positive and significant impact on organizational performance in education office of Kerman province.

\section{RESULTS}

Direct Effect of Organizational Culture on APIP Performance. Based on the results of statistical verification research that Organizational Culture contributes to Performance. From the statistics it is known that tcount $>$ ttable, expressed a positive and significant direct effect. In this case the Organizational Culture will have a greater influence on performance, by improving the indicators of Discipline, Efficient, and Ethics, implementation of work, the scope of work, and work orientation. This research is supported by theory Colquitt Jason A, etc. (2009), organizational culture is closely related to rules, norms, and values adopted by employees. This research is supported by theory Luthan (2011), Some important characteristics of organizational culture are the regularity of observed behaviour, norms, dominant values, philosophy, rules, and organizational climate.

This research is supported by theory Robin Stuart Kotze (2006), In what has to be seen as bad news for instructors in business studies programmes around the world, they found that none of these management practices had any direct causal relationship to superior business performance. But what they did find was that there were a small number of basic management practices that, without exception, characterized companies that consistently outperformed their industry. Among these were culture and execution. To word, Continuous performance improvement has to become part of an organization's culture one of its strongly held values and it has to be consistently applied.

Research supported Slocum \& Hellriegel (2009), Organizational culture has the potential to change organizational performance, individual satisfaction, the sense of certainty about how problems are to be handled, and so on. However, if an organizational culture gets out of step with the changing expectations of internal and/ or external stakeholders, the organization's effectiveness can decline. Organizational culture and performances are clearly related, although the evidence regarding the exact nature of this relationship is mixed. Studies show that the relationship between many cultural attributes (featured in the popular press as being important for performance) and high performance hasn't been consistent over time.

This research is also supported from the journal by Amin Nikpour (2017), Indicated that organizational culture has a positive and significant impact on organizational performance. In line with that Sunday I. Efanga explain in, Caroline O. Ifejiagwe (2014), that organization with strong culture would lead to high performance. Some recommendations were preferred among which, that management should adopt the values, norms to support teacher and this performance in organizations. This research is also supported from the journal by Walid EL Laeithy (2017), Relationship with organizational culture from one side and organizational performance from the other. In the meantime, the study's findings eliminate the role of corporate culture in financial per-

* $\quad$ The Effect Of Organizational Culture On Performance Of Government Internal Supervisory Apparatus (Apip) In The National Indonesian Navy. 
formance's difference between multinational companies and local one operating in the Egytian market. This research is also supported from the journal by M. Shakil Ahmad (2012), Organizational performance management system create career paths for employees as well as groupings of people who remain in the firm for a long enough time for a company culture to form. Based on the above explanation, it can be concluded that the results of this study support previous research about the positive direct influence of Organizational Culture on Performance.

\section{CONCLUSION}

Organizational Culture has a direct effect on Performance. This shows that the Organizational Culture is well run so it will lead to increased performance. Implications, Organizational Culture is enhanced by spurring discipline, efficiency, ethics, scope of work, work orientation and work implementation instructions. It will result in improved APIP performance in the Navy, suggestion. In order to increase APIP Performance in the Navy. The Leader conducts selection of APIP candidates. After being APIP refresher is needed in the form of training to determine the extent of the development of rules and references used. The opportunity is adjusted to the schedule to avoid the same time as supervisory activities.

\section{REFERENCE}

Amin Nikpuour, The impact of organizational culture on organizational performance: the mediating role of employee's organizational commitment. International Journal of Organizational Leadership 6 (2017) 65-72,

Colquitt, Jason A, Jeffery A. LePine \& Micchael J. Wesson. Organizational Behavior. Improving Performance and Commitment in the Workplace. New York: McGraw Hill, 2009. 2011.

Fred Luthans. Organizational behavior. 12th Edition. McGraw-Hill Companies,

Gavric, G., Sormaz, G., \& Ilic,D (2016). The impact of Organizational culture on the ultimate performance of company, International Review, (3-4), 25-30.

M. Shakil Ahmad., Impact of Organizational culture on performance management practices in Pakistan., Business intelegence journal- January, 2012 Vol. 5 no.1.

Robbin Stuart-Kotze, Performance The Secret of Successful Behavior.2006, fist published in Gread Britain in 2006, ISBN- 13.978.0.273-70798-1; ISBN-10-0-27370798-1.

Salihu, Adam Jiddah, Salihu, Muhammad Bello Rayyan \& Musa Idris Umar. Impact of organizational culture on employee performance in Negeria. International journal of novel research in marketing maganenet and economics. Vol.3, Issue 3, pp (48-65), Month: September-December 2016.

Slocum, John W, Jr \& Don Hellriegel, Principles of Organizational Behavior, Twelth Edition, USA: South Western, Cengage Learning. 2009.

Sunday I. Efanga, \& Caroline O. Ifejiagwa., Influence of organizational culture on performance management practices in secondary schools in akwa ibom state, Negeria., International Journal of Humanities and social science. Vol. 4. No.6: April 2014

Walid EL Laeithy,International Journal of Economics \& managemens sciences, Organizational culture and Organizational performance. Vo. 6. Issue 4, 2017, 1000442 .

* The Effect Of Organizational Culture On Performance Of Government Internal Supervisory Apparatus (Apip) In The National Indonesian Navy.

* $\quad$ https://doi.org/10.21009/JOBBE.003.1.03 